\title{
A Contribution to the Epipelic Algal Ecology in Lotic Ecosystem of Iraq
}

\author{
Fikrat M. Hassan ${ }^{*}$, Ali Obaid Shaawiat ${ }^{2}$ \\ ${ }^{1}$ College of Science for Women, University of Baghdad, Baghdad, Iraq \\ ${ }^{2}$ College of Education, University of Al-Qadisiyah, Al Diwaniyah, Iraq \\ Email: fikrat@csw.uobaghdad.edu.iq
}

Received 18 January 2015; accepted 2 February 2015; published 5 February 2015

Copyright (C) 2015 by authors and Scientific Research Publishing Inc.

This work is licensed under the Creative Commons Attribution International License (CC BY).

http://creativecommons.org/licenses/by/4.0/

c) (i) Open Access

\section{Abstract}

The study was conducted on epipleic diatoms in a lotic ecosystem. The Al-Shamiyah River was selected which is a distance from industrial activities. Four sites along the river were selected for sampling during the period from March 2013 to February 2014. A total of 173 species of epipelic diatoms were identified. The pennate diatoms predominated and represented about $92.49 \%$ of the total diatoms, while centric diatoms formed only $7.51 \%$. The total number of diatoms ranged between $185.1-422.34$ cell $\times 10^{4} / \mathrm{cm}^{2}$. Some of the pennate diatom species were Achnanthes affinis Grunow, Achnanthes mintussima Küetzing, Cocconeis placentula var. euglypta (Ehr.) Cleve, Cymbella affinis Küetzing, Diatoma vulgare Bory, Fragilaria capucina Desmazieres, Gomphonema angustatum var. productu Grun., Navicula lanceolata (Ag.) Kuetzing, Navicula radiosa Küetzing, Navicula viridula Küetzing, Nitzschia palea (Kutz.) W. Smith, Nitzschia romana Grunow. The physicochemical and epipelic algae species indicated that the water quality of the river was clean to moderate water quality.

\section{Keywords}

Diatom, Epipelic Algae, Lotic System, Euphrates River

\section{Introduction}

The importance of benthic algae in Iraqi aquatic ecosystems was subjected to investigations recently [1]-[4]. Many authors have previously recognized benthic algae as bioindicators in different aquatic ecosystems of Iraq [5]-[7].

Benthic algae play a role as energy source for many benthic fauna. Moreover, their roles in recycling nutrients

"Corresponding author. 
(through the water column and sediment) and transformation of inorganic material into organic via photosynthesis in sediment were also known. Also, it was considered as oxygen sources for the water and sediment [7]-[9]. The benthic algae were considered as resistant to alterations of the environment and pollution due to their ability to attach to benthic substrates [10].

The abundance of diatomic algae was also observed in different studies. The abundance of some diatomic species may reflect the status of the aquatic ecosystem such as the trophic status [11] or extent of organic pollution [1] [5] and to water quality [3]. Many authors have pointed out the abundance of diatoms and explained that the diatomic algae had the ability to alter the conditions of their environment, but their community structure responded to altered physicochemical and biological variables in the ecosystem [12]-[14].

Al-Lami et al. [15] observed high diversity of epipelic algae in four aquatic systems having a gradient of salinity in central of Iraq. Essa [16] used diatoms as bioindicators in some aquatic systems in Basra region, Iraq, where the author stated that the status of these sites ranged between oligo-mesotrophic and mesotrophic except only one site which was trophic.

This investigation is the first attempt to fill the gap of information about epipelic algal ecology in Al-Shamiyah River and the possibility to use epipelic algae as bioindicators.

\section{Material and Methods}

Four sites were selected along a branch of the Euphrates River, the Al-Shamiyah River (a Lotic System). The branch originates after passing Kifil city in the middle region of Iraq, and passes through the Shamiyah town which is just $284 \mathrm{~km}$ from Baghdad city (the capital of Iraq) and only $40 \mathrm{~km}$ from Al-Diwanyiah Province. The river converges with the Kufa River (a second branch of Euphrates River) at Shinafya town. The selected sites (Figure 1) were characterized by vast agricultural activity and the presence of macrophytes (sites 1, 2 and 3), while site 4 was located within a paddy field having dense growth of macrophytes.

All physicochemical parameters were measured according to the methods of APHA [17], Parsons et al. [18] and Gaudette et al. [19] (for Total Organic Carbon (TOC\%). Biological diversity indices (Species richness and Shannon-Weaver) were calculated according to Magurran [20]. Canonical Corresponded Analysis (CCA) Ver. 4.5 was applied for the statistical analysis.

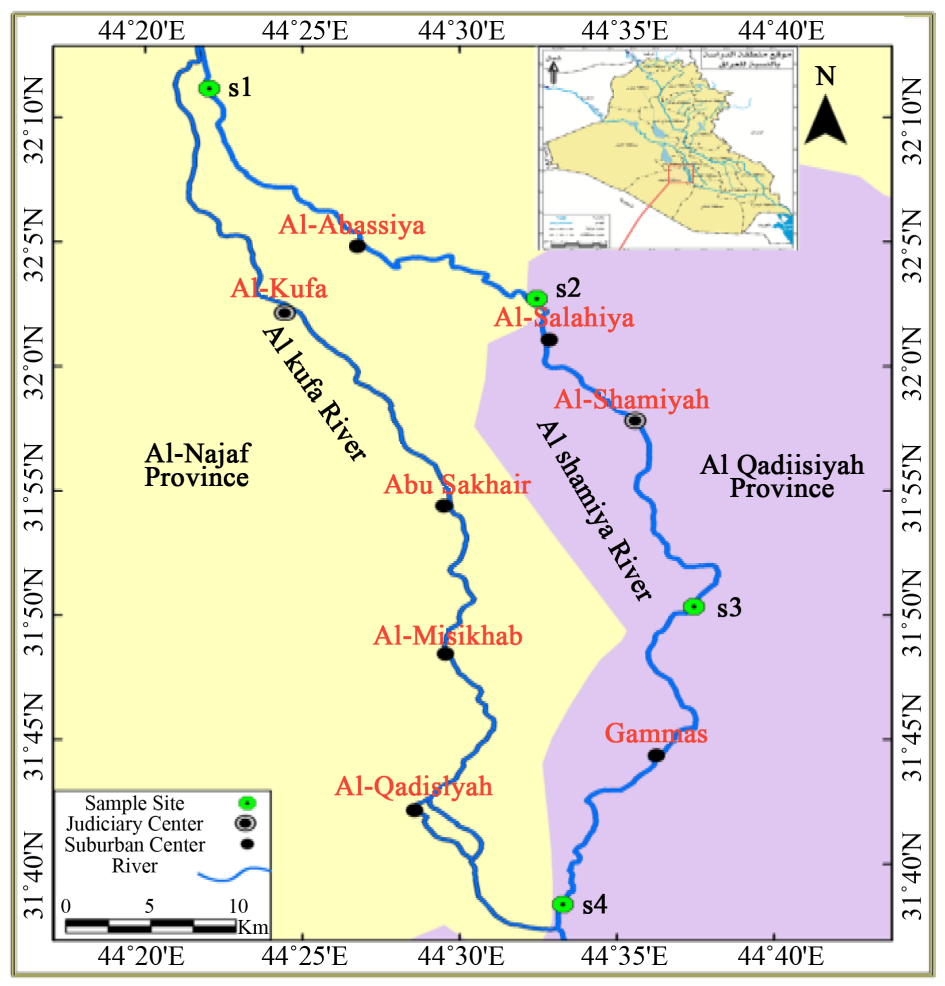

Figure 1. Map of the studied area. 
Epipelic algae samples were taken according to Eaton and Moss [21]. Microtransect method was used for estimation of the total number of epipelic algae after preparing permanent slides [21]. Identification of epipelic algae relied on description given in the following references: [22]-[26].

\section{Results}

The physicochemical parameters of the Al-Shamiyah River were already discussed in terms of seasonal and spatial variation [27]. In winter (December and February 2014) and summer 2013 (August 2013), respectively, air and water minimum temperature (AT and WT) were not less than $11^{\circ} \mathrm{C}$, while maximum did not exceed $39^{\circ} \mathrm{C}$ (Table 1). Water flow rates ranged between 20 meter $/ \mathrm{min}^{-1}$ at site 3 in April 2013 and $49.99 \mathrm{~meter} / \mathrm{min}^{-1}$ at site 1 in January 2014. Records of turbidity (Tur) were Low in April 2013 (8.25 NTU) while higher value (22.11 NTU) was recorded in January 2014 at sites 3 and 1, respectively. Electric conductivity (EC) and salinity (S\%o) ranged $1108-1560 \mu / \mathrm{cm}$ and $0.71 \%$ - $0.99 \%$, respectively. Total suspended solids (TSS) value was higher at site 1 (39.02 mg/l) and low (16.50 mg/l) at site 3 in January 2014 and April 2013, respectively. Light penetration (LP) ranged between 24.40 and $65.00 \mathrm{~cm}$ at sites 1 and 3 in January 2014 and April 2013, respectively. All pH values were higher than 7.00 and reached 8.23 during most of the study period. Total alkalinity (TA) values ranged between 97 and $162 \mathrm{mg} / \mathrm{l}$ at sites 1 and 4 in September and June 2013, respectively.

No anoxia was recorded in this study and dissolved oxygen (DO) concentrations ranged between 6.30 and $10.5 \mathrm{mg} / \mathrm{l}$ (Table 1). The lowest recorded concentration was in July 2013 while the highest was in February 2014. Maximum value of biochemical oxygen demands $\left(\mathrm{BOD}_{5}\right)(2.50 \mathrm{mg} / \mathrm{l})$ in August 2013 at site 4 and the lowest value was $0.99 \mathrm{mg} / \mathrm{l}$ at site 1 . Total hardness $(\mathrm{TH})$, calcium (Ca), and magnesium (Mg) concentrations ranged between 259.63 and $572.00 \mathrm{mg} \mathrm{CaCO}_{3} / \mathrm{l}, 74.41$ and $150.55 \mathrm{mg} / \mathrm{l}, 12.57$ and $63.10 \mathrm{mg} / \mathrm{l}$ during the study period, respectively for sites 1 to 4 .

Table 1. Range of physicochemical parameters in Al-Shamiyah River during the study period.

\begin{tabular}{|c|c|}
\hline Parameter & Range \\
\hline Air temp. $\left({ }^{\circ} \mathrm{C}\right)$ & $13.33-39.00$ \\
\hline Water temp. $\left({ }^{\circ} \mathrm{C}\right)$ & $11.00-36.00$ \\
\hline Water flow (m/min) & $20.00-49.99$ \\
\hline Turbidity (NTU) & $8.25-22.11$ \\
\hline Light penetration $(\mathrm{cm})$ & $24.40-65.00$ \\
\hline Electric $\mathrm{C}$ conductivity $(\mu \mathrm{s} / \mathrm{cm})$ & $1108-1560$ \\
\hline Salinity \%o & $0.71-0.99$ \\
\hline Total dissolved solids (mg/l) & 709 - 998 \\
\hline Total suspended solids (mg/l) & $16.50-39.02$ \\
\hline $\mathrm{pH}$ & $7.46-8.23$ \\
\hline Dissolved oxygen mg/l & $6.30-10.50$ \\
\hline Biochemical oxygen demand mg/l & $0.99-2.5$ \\
\hline Alkalinity mg $\mathrm{CaCO}_{3} / \mathrm{l}$ & $97-162$ \\
\hline Hardness mg $\mathrm{CaCO}_{3} / \mathrm{l}$ & $259.63-572$ \\
\hline Calcium mg/l & $74.41-150.55$ \\
\hline Magnesium mg/l & $12.57-63.10$ \\
\hline Nitrite $\mu g / l$ & $0.16-2.20$ \\
\hline Nitrate $\mu \mathrm{g} / \mathrm{l}$ & $40.38-117.46$ \\
\hline Phosphate $\mu \mathrm{g} / \mathrm{l}$ & $0.012-0.22$ \\
\hline Silicate $\mu \mathrm{g} / \mathrm{l}$ & $93.13-160.8$ \\
\hline Total organic carbon mg/l & $0.24-1.85$ \\
\hline
\end{tabular}


Nutrient concentration records showed resemblance among river's sites. Mean concentration of nitrite $\left(\mathrm{NO}_{3}\right)$, nitrate $\left(\mathrm{NO}_{2}\right)$, phosphate $\left(\mathrm{PO}_{4}\right)$ and silicate $\left(\mathrm{SiO}_{3}\right)$ ranged between 1.22 and 154, 57.00 and 73.00, 0.01 and 0.12, 120.25 and $140.73 \mu \mathrm{g} / \mathrm{l}$, respectively for sites 1 to 4 .

A total of 173 taxa of epipelic algae were identified in this study. At site four 108 species were recorded while at sites 1 to 3: 89, 96 and 98 species were recorded, respectively. There were different numbers of genera and species recorded among the study sites (Table 2 and Table 3). It is evident that pennate diatoms were dominant and represented $92.49 \%$ of the total identified diatoms. The pennate diatoms however represented: $91.01 \%$, $91.67 \%, 91.84 \%$ and $92.59 \%$ at sites 1, 2, 3 and 4, respectively. The centric diatoms represented between $7.42 \%$ and $8.99 \%$ where the lowest percentage was at site 4 and the highest at site 1 .

Some of the species recorded in this study were present in high numbers contrasting those of other epipelic algae. Four species recorded for each of the genera: Cyclottela, Achnanthes, and Cocconeis at site 1. While Cymbella, Gomphonema, Gyrosigma, Navicula and Nitzschia recorded 6, 5, 5, 10 and 20 at the same site, respectively. These genera also were recorded in other sites with different numbers of species. While the higher number of species, (26 species for Nitzschia) was recorded at site 4. While the genera Cymbell and Gomphonema were represented by ten species at sites 3 and 4 . Number of Navicula species ranged between 10 and 16 at site 1 and 3, respectively.

Some species were present for the most period and sites of the study (Table 4). At site 1, the following species were found: A. ambigua, C. ocellata, C. menenghiana, C. placentula var. euglypta, C. affinis, G. angustatum var. productum, $N$. radiosa, $N$. viridula, $N$. romana, S. ulna. While at site 2 species present were as follows: C. menenghiana, A. affinis, C. lacustris, C. affinis, D. vulgare, G. angustatum var. productum. However, at site 3 species present were A. ambigua, C. lacustris, C. placentula var. euglypta, $N$. viridula, $N$. romana, and $N$. palea, while at site 4 species present were A. ambigua, C. lacustris, C. menenghiana, C. ocellata, $N$. viridula, S. ulna and Gyrosigma acuminatum, G. angustatum var. productum.

Total number of epipelic algae ranged $185.154 \times 10^{4} / \mathrm{cm}-422.345 \times 10^{4} / \mathrm{cm}$ at sites 2 and 4 , respectively. Seasonal variation of the total number of epipelic algal species was observed in this study. For centric diatoms, Aulacoseira ambigua $\left(0.51-2.31\right.$ cells $\times 10^{4} / \mathrm{cm}^{2}$ at sites 2 and 4$)$, C. menenghiana $\left(1.17-7.86\right.$ cells $\times 10^{4} / \mathrm{cm}^{2}$ at sites 1 and 3), C. ocellata ( $0.66-6.45$ cells $\times 10^{4} / \mathrm{cm}^{2}$ at sites 2 and 4$)$. Most of high total number for pennate diatoms was recorded at site 4 . Total number of some pennate diatoms were as follows: $4.92-35.79$ cells $\times$ $10^{4} / \mathrm{cm}^{2}$ for G. angustatum var. productum at sites 3 and $4,1.3-20.94$ cells $\times 10^{4} / \mathrm{cm}^{2}$ for $N$. palea at sites 2 and 3, $1.2-19.11$ cells $\times 10^{4} / \mathrm{cm}^{2}$ for C. affinis at sites 1 and $4,11.28-17.46$ cells $\times 10^{4} / \mathrm{cm}^{2}$ for A. affinis at sites 3 and 2 , respectively.

Table 2. Range (Mean \pm SD) biological parameters in Al-Shamiyah River during the study period.

\begin{tabular}{ccccc}
\hline Parameters & Site 1 & Site 2 & Site 3 & Site 4 \\
\hline Total diatoms algae cell $\times 10^{4} / \mathrm{cm}^{2}$ & $6.75-44.49$ & $3.75-42.51$ & $2.28-59.13$ & $3.87-115.8$ \\
& $(20.78 \pm 12.97)$ & $(15.42 \pm 13.12)$ & $(26.96 \pm 18.09)$ & $(35.19 \pm 31.02)$ \\
Chlorophyll a $\mu \mathrm{g} / \mathrm{cm}^{2}$ & $0.36-1.66$ & $0.07-1.45$ & $0.07-6.72$ & $0.07-2.24$ \\
& $(1.08 \pm 0.48)$ & $(0.67 \pm 0.54)$ & $(1.72 \pm 2.25)$ & $(0.7 \pm 0.64)$ \\
Pheophytin a $\mu \mathrm{g} / \mathrm{cm}^{2}$ & $0.08-1.16$ & $0.012-0.61$ & $0.04-2.64$ & $0.03-0.98$ \\
& $(0.36 \pm 0.32)$ & $(0.19 \pm 0.23)$ & $(0.63 \pm 0.71)$ & $(0.25 \pm 0.27)$ \\
\hline
\end{tabular}

Table 3. Total number of genera and species of centrals (C) and pennales (P) of epipelic algae in the studied sites (S) during the study period in Al-Shamiyah River.

\begin{tabular}{cccccccccccc}
\hline & \multicolumn{3}{c}{ S1 } & \multicolumn{3}{c}{ S2 } & \multicolumn{3}{c}{ S3 } & & S4 \\
\hline & C & P & C & P & C & P & C & P \\
Genera & 3 & 22 & 3 & 24 & 4 & 25 & 4 & 20 \\
Species & 8 & 81 & 8 & 88 & 8 & 90 & 8 & 100 \\
Percent (\%) & 8.99 & 91.01 & 8.33 & 91.67 & 8.16 & 91.84 & 7.42 & 92.59 \\
Total genera & 22 & & 25 & & 29 & & 24 & \\
Total species & 89 & & 96 & & 98 & & & 108 \\
\hline
\end{tabular}


Table 4. List of some dominant epipelic taxa and its total number (cell $\times 10^{4} / \mathrm{cm}^{2}$ ) during the study period in Al-Shamiyah River.

\begin{tabular}{|c|c|c|c|c|}
\hline Aulacoseira ambigua $\mathrm{O}$. Muller & 0.66 & 0.51 & 1.95 & 2.31 \\
\hline A. Dicikiei (Thwaites) Kutzing & 0.21 & - & - & - \\
\hline A. distanse (Ehr.) Kutz & - & 0.09 & - & - \\
\hline A. granulate (Ehr.) Ralfs & 0.3 & 0.69 & 0.21 & 0.72 \\
\hline Cycllotella comta (Ehr.) Kuetzing & 0.57 & 0.12 & 7.95 & 0.3 \\
\hline C. glomerata Bachmann & - & - & - & 0.12 \\
\hline C. kuetzingiana Thwaites & - & 1.95 & - & - \\
\hline C. menenghiana Kuetzing & 1.17 & 1.98 & 7.86 & 3.18 \\
\hline C. ocellata Pantocsek & 6.42 & 0.66 & 1.47 & 6.45 \\
\hline C. stelligera Cleve et Grunow Van Heurck & - & - & 0.54 & - \\
\hline Achnanthes affinis Grunow & 14.01 & 17.46 & 11.28 & 15.33 \\
\hline A. hungarica Grunow & 13.02 & - & 0.33 & - \\
\hline A. lanceolata Grunow & - & - & - & 0.06 \\
\hline A. linearis W. Smith Grunow & - & - & 6.81 & - \\
\hline A. microcephala (Ktz.) Grunow & 0.33 & 4.68 & 0.12 & 12.69 \\
\hline A. mintussima Küetzing & 0.75 & 15.48 & 0.06 & 17.79 \\
\hline A. saxonic Krasske & 0.12 & - & - & - \\
\hline Cocconeis pediculus Ehrenberg & 2.01 & 0.51 & - & 1.62 \\
\hline C. placentula Ehrenberg & 5.43 & 11.4 & 4.38 & 1.95 \\
\hline C. placentula var. euglypta (Ehr.) Cleve & 10.41 & 9.39 & 7.08 & 16.11 \\
\hline Cymbella affinis Küetzing & 1.2 & 7.5 & 2.13 & 19.11 \\
\hline Cymbella aspera H. paragallo & - & 0.33 & - & 0.24 \\
\hline C. caespitosa (Kutz.) Brun & - & - & - & 6.45 \\
\hline C. cistula (Ehr.) Kirchn & 0.36 & 0.24 & - & - \\
\hline C. gracilis (Rabh.) Cleve & - & - & - & 6.99 \\
\hline C. helvetica Kuetzing & 0.18 & 0.51 & - & 0.06 \\
\hline C. lanceolata & - & 0.3 & - & - \\
\hline C. obtusiuscula (Kutz.) Grun & - & - & - & 0.06 \\
\hline C. parva (W. Smith) Kitchn & - & - & 0.18 & - \\
\hline C. tumida (Bréb.) V. Heurck & 0.51 & 1.17 & 1.83 & 4.83 \\
\hline C. tumidula Grun & - & - & - & 0.24 \\
\hline C. turgida (Greg.) Cleve & 5.52 & 0.21 & - & 0.12 \\
\hline Gomphonema acuminatum Ehr. & - & 0.09 & 15.45 & - \\
\hline G. acuminatum var. turris Cleve & - & - & - & 0.06 \\
\hline Gomphonema angustatum (Ktz.) Rabenhorst & 5.67 & 0.9 & 1.32 & \\
\hline G. angustatum var. product Grun & 11.28 & 11.73 & 4.92 & - \\
\hline G. augur Ehrenberg & - & - & 0.66 & 35.79 \\
\hline G. constrictum Eher & - & - & - & - \\
\hline G. constrictum var. capitat (Ehr.) Cleve & - & - & 0.36 & 0.06 \\
\hline
\end{tabular}




\section{Continued}

\begin{tabular}{|c|c|c|c|c|}
\hline G. gracile Ehrenberg & - & 1.05 & 6.96 & 0.12 \\
\hline G. intricatum Küetzing & 0.18 & 0.24 & 0.09 & 8.04 \\
\hline G. intricatum var. lunata nov & 8.82 & 10.95 & 0.18 & 0.6 \\
\hline G. lanceolatum Ehrenberg & 0.15 & 0.18 & 1.17 & 10.5 \\
\hline G. parvulum (Kuetz) Grun & - & - & - & 6.57 \\
\hline Gyrosigma acuminatum (Ktz.) Rabenhorst & 0.36 & 0.21 & 4.29 & 0.06 \\
\hline G. attenuatum (Ktz.) Rabenhorst & 1.02 & 0.06 & 0.09 & 0.96 \\
\hline G. scalproides (Raben) Cleve & 0.12 & & - & - \\
\hline G. macrum (W. Smith) Griff et. Henfr & - & 0.24 & - & - \\
\hline G. spenceri (Quek) Griff et Henfr & 0.15 & - & - & - \\
\hline G. tenuirostrum (Grun.) Cleve & 0.18 & - & - & - \\
\hline Fragilaria brevistriata Grunow & - & - & 1.35 & - \\
\hline F. capucina Desmazieres & 0.48 & 1.02 & 15.21 & - \\
\hline F. construens Grunow & - & - & - & 14.43 \\
\hline F. construens var. subsalina Hust. & - & 0.03 & - & 0.06 \\
\hline F. crotonensis Kitton & 1.11 & 0.42 & 3.69 & - \\
\hline F. intermedia Grunow & 0.21 & 1.53 & 1.44 & 7.14 \\
\hline Navicula angilica Ralfs & - & 0.15 & 0.09 & 1.14 \\
\hline N. angilica var. subsulsa & - & - & 1.56 & - \\
\hline N. bacillum Ehrenberg & - & - & 0.09 & - \\
\hline N. cincta (Ehr.) Kuetzing & 9.57 & 5.07 & 6.81 & 3.57 \\
\hline N. creptocephala Kuetzing & 9.75 & 0.15 & 4.26 & 0.18 \\
\hline N. decussis Oestrup & - & 0.06 & - & - \\
\hline N. dicephala W. Smith & - & - & 0.18 & 4.2 \\
\hline N. fusca Greg & - & 0.12 & - & - \\
\hline N. gibbula Cleve & - & - & - & 0.03 \\
\hline N. gracilis & 0.39 & 1.08 & 2.01 & 5.34 \\
\hline N. graciloides A. Mayer & - & - & 7.44 & - \\
\hline N. gregaria Donkin & - & - & - & 0.06 \\
\hline N. grimmei Krasske & - & 0.78 & 0.66 & 1.35 \\
\hline N. halophila (Grun.) Cleve & 14.97 & 0.9 & 0.54 & 1.89 \\
\hline N. lanceolata (Ag.) Kuetzing & 13.5 & 5.85 & 7.14 & 8.97 \\
\hline N. mutica Kuetzing & 0.24 & 0.45 & - & - \\
\hline N. parva (Menegh) Cleve & 0.15 & - & - & - \\
\hline N. phyllepta Kuetzing & 5.43 & - & 1.35 & 6.87 \\
\hline$N$. radiosa Küetzing & 22.41 & 17.58 & 40.35 & 14.67 \\
\hline N. rhynchocephala Kuetzing & - & - & 0.24 & - \\
\hline N. schroeteri Meister & - & - & 7.56 & - \\
\hline N. spicula (Hickie) Cleve & - & 0.45 & - & - \\
\hline N. viridula Ktz. & 10.08 & 0.36 & 16.59 & 9.36 \\
\hline Nitisha acicularis (Ktz.) W. Smith & 0.42 & 0.93 & 0.99 & 0.18 \\
\hline N. acuta Hantzsch & 0.06 & - & - & 0.24 \\
\hline N. amphibia Grunow & - & 0.09 & - & - \\
\hline
\end{tabular}




\section{Continued}

\begin{tabular}{|c|c|c|c|c|}
\hline N. apiculata (Greg.) Grunow & 0.18 & 0.9 & - & 0.12 \\
\hline N. circumsuta & 0.3 & - & - & - \\
\hline N. clausii Hantzsch & - & 6.6 & 0.3 & 5.25 \\
\hline N. commutata Grun & 0.03 & - & - & - \\
\hline N. dissipata (Ktz.) Grunow & 8.1 & 0.09 & 0.3 & 11.73 \\
\hline N. dubia W. Smith & - & 0.54 & - & - \\
\hline N. fasciculate Grunow & - & - & - & 0.15 \\
\hline N. filiforms (W. Smith) Hustedt & 0.12 & - & 0.12 & 1.29 \\
\hline N. fonticola Grunow & - & 0.09 & - & - \\
\hline N. gracilis Hantzsch & 1.92 & 0.18 & 0.6 & 9.24 \\
\hline N. hantzschiana Rabh & 0.12 & - & 0.63 & 0.24 \\
\hline N. hungarica Grunow & 0.48 & 0.63 & 0.6 & 0.63 \\
\hline N. ignorata Krasske & - & - & - & 0.12 \\
\hline N. inconspicua Grun & - & -- & - & 10.02 \\
\hline N. intermedia Hantzsch ex Cleve \& Grunow & 0.12 & 2.19 & 0.24 & 6.66 \\
\hline N. linearis W. Smith & 2.85 & 0.18 & 1.8 & 0.12 \\
\hline N. lottoralis Grunow & 0.15 & - & - & - \\
\hline N. longissima Ralfs & 0.15 & 0.12 & 0.69 & 0.27 \\
\hline N. microcephala Grun & - & 0.21 & 0.15 & 6.21 \\
\hline N. obtusa W. Smith & - & - & - & 0.12 \\
\hline N. palea (Kutz.) W. Smith & 4.29 & 1.32 & 20.94 & 7.14 \\
\hline N. puctata (W. Smith) Grunow & 0.15 & - & - & - \\
\hline N. pusilla (Kutz.) Grunow & 0.15 & - & 1.77 & 0.39 \\
\hline N. recta Hantzsch & - & - & 12.27 & 6.57 \\
\hline N. romana Grunow & 7.35 & 10.23 & 24.66 & 24.51 \\
\hline N. rostellata Hustede & - & - & 0.42 & - \\
\hline N. sigma W. Smith & - & - & - & 0.06 \\
\hline N. sigmoidea (Ehr.) W. Smith & 0.24 & 0.99 & - & 1.41 \\
\hline N. stagnorum Rabh & - & 0.15 & - & - \\
\hline N. sublinearis Hustedt & - & 0.18 & - & - \\
\hline N. tryblionella Hantsch & 5.7 & - & 0.69 & 0.15 \\
\hline N. tryblionella var. debilis A. Mayer & - & - & 0.12 & \\
\hline N. tryblionella var. levidensis Grunow & - & 0.87 & 10.29 & 0.24 \\
\hline N. umbonate (Ehrenberg) Lange 0 Bertalot & - & - & 0.12 & - \\
\hline Synedra acus Kuetzing & 0.18 & 0.54 & 0.21 & 1.29 \\
\hline S capitata Ehrenberg & - & 0.06 & 1.05 & 0.09 \\
\hline S. pulchella (Ralfs) Kuetzing & - & 0.09 & - & 0.09 \\
\hline S. rumpens Kg & - & - & - & 0.12 \\
\hline S. tabulata var. fasciculate Agardh & 0.09 & 0.06 & 0.09 & 0.21 \\
\hline S. ulna (Nitz.) Ehrenberg & 8.91 & 3.6 & 0.54 & 7.86 \\
\hline S. vaucheriae Kuetzing & 0.36 & 0.6 & 0.9 & 0.06 \\
\hline
\end{tabular}

Minimum value of Chlorophyll-a concentration ranged between 0.07 and $6.72 \mu \mathrm{g} / \mathrm{cm}^{2}$ at sites 2,3 and 4 (Table 2), while the maximum values were recorded at site 3 in late winter 2014 and autumn 2013, respectively. 
Phaeophytin-a concentration ranged between 0.012 and $2.64 \mu \mathrm{g} / \mathrm{cm}^{2}$ in late winter 2014 and spring 2013, respectively. For both chlorophyll-a and phaeophytin-a significant variation $(\mathrm{P}<0.05)$ among concentrations, sites and seasons were noticed.

Index of species richness ranged between 7.46 at site 4 in spring 2013 and 27.91 at site 3 in autumn 2013. While Shannon Species Diversity index showed high values $(>1)$ at all studied sites, and ranged between 1.35 3.23 at sites 2 for both valuesin summer and autumn 2013, respectively. For both estimations of biodiversitya significant difference $(\mathrm{P}<0.05)$ was recorded among sites and seasons. Figure 2 illustrated the spatial and temporal variation of the studied biological diversity. Figure 3 illustrated CCA analysis ofspecies-environment correlations.

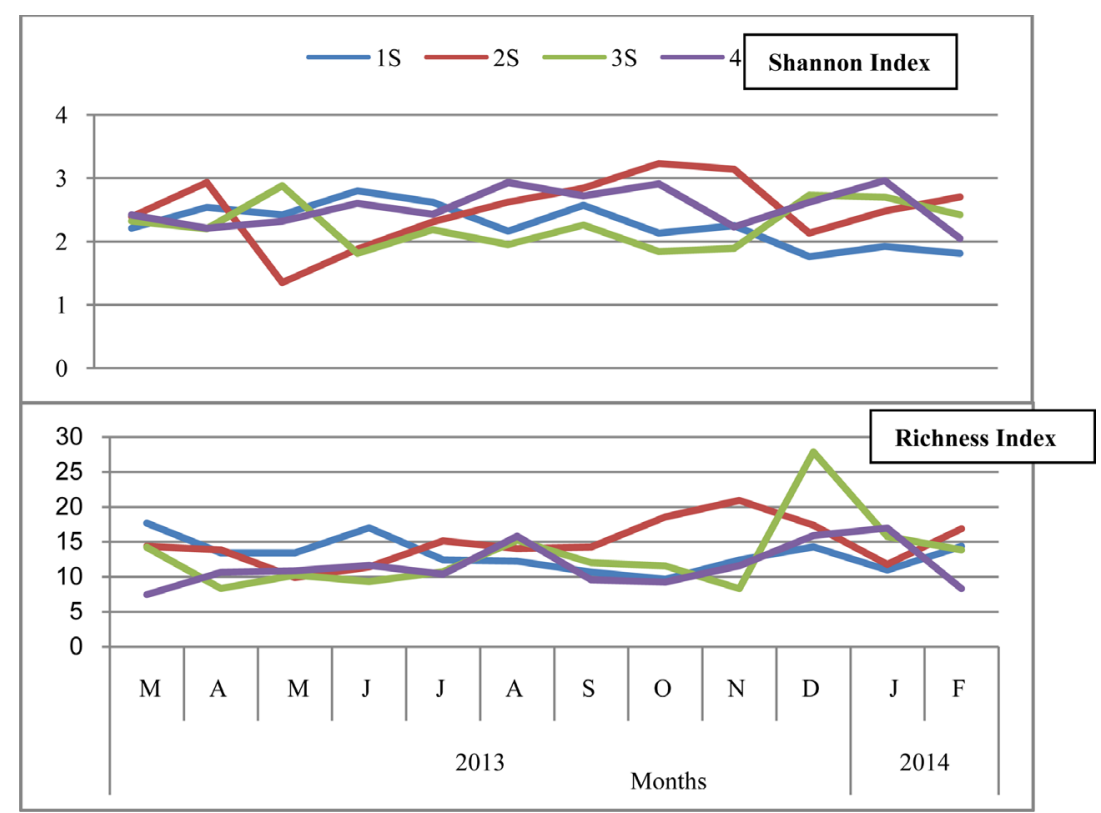

Figure 2. Spatial and temporal variations of the studied biological indices in AlShamaiyah.

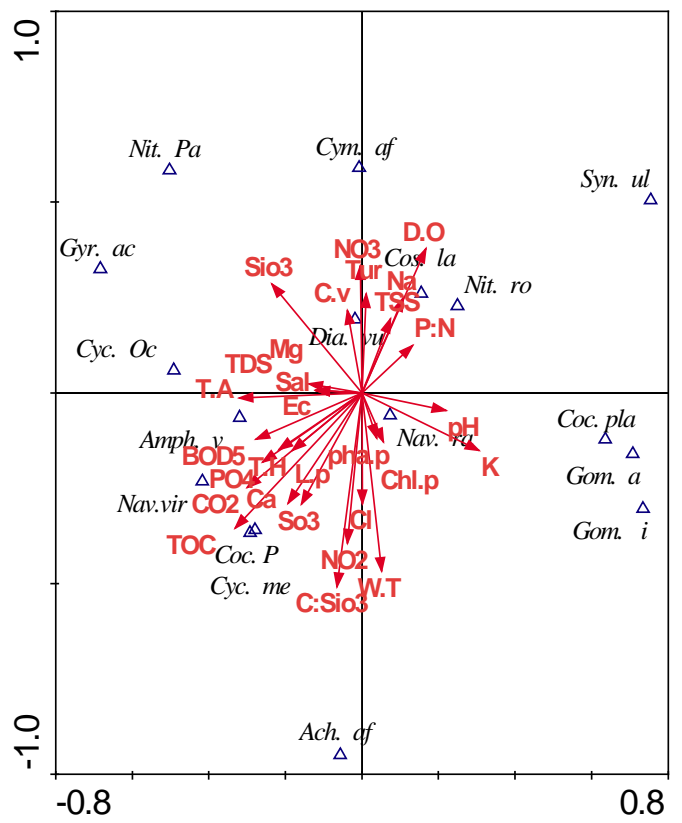

Figure 3. CCA analysis of species-environment correlations. 


\section{Discussion}

Both the air and water temperatures varied with season where lowest values were recorded in winter and the highest in summer. These findings were similar to observations made in previous studies in Iraqi aquatic ecosystems [28]-[31]. These results may be explained in view of Iraq's climate being continental and subtropical [32]. Water flow rate variation mostly affected mainly by operation of river regulation and channel morphology [33] [34]. Also, light penetration influenced by means of physical and chemical properties of the river. These factors include turbidity, water drainage, the density of microorganism (including phytoplankton) and macrophytes cover [35]. EC, salinity, and TDS values recorded exceeded levels recorded in previous studies in Euphrates River [2]-[28]. According to APHA [17] and SWRCB [36] as mentioned by Manivanan [37], the river is considered within freshwater, in which the conductivity range between 100 and $2000 \mu \mathrm{S} / \mathrm{cm}$, and brackish water in the range of $0.5 \%$ o to $29 \%$. The Iraqi natural water ecosystems are known to be of buffer capacity of alkaline to hard water [38] [39]. Well-oxygenated water in the river was noticed during the study period, and the highest values recorded in spring may be due to the increasing photosynthesis activity during this season and low temperature during the summer. BOD5 results reflected that Al-Shamiyah River was clean to moderately polluted river [40]. These results did not indicate a limitation role for nutrients in algae.

Spatial and temporal variations of epipelic algae in the studied river were obvious. The variation might be due to the different environmental characteristics among sites and seasons in addition to the texture of sediment. The dominance of diatoms in benthos ecosystems was well known. This dominance may be due to their ability to adapt in an altering environment with less available light intensity [41]-[43]. This dominance is also referred to in other studies of aquatic ecosystems in Iraq [1]-[3].

It is very known that in freshwater ecosystems the pinnate diatoms are predominate, while in marine ecosystems the centric diatoms are predominate [44]. Results of the present investigation confirmed the latter authors' findings. The density of epipelic algae was related to many factors. These factors may be that some algae have the ability to reproduce in unsuitable conditions. In addition to that, their ability to secrete mucilage sheath that helps their daily rhythms [7]. Moreover, algal adhesion affected by nutrient concentrations, grazing process and other factors [2] [45]. Temporal variation may be due to the climate characteristics of the study area that lies within the hot desert climate. Iraq is characterized by great temperature diurnal and seasonal variations. Most of the high number of total epipelic algae in spring and autumn during this study. These results also were noticed by other researchers in Iraqi aquatic ecosystems [1] [2]. Chlorophyll-a concentration did not exceed 2.24 to 2 $\mu \mathrm{g} / \mathrm{l}$, and may be attributed to the oligotrophic status of the river [46] [47]. Nutrient concentrations and other physicochemical factors affect chlorophyll-a concentration and epipelic algae growth [48]. CCA analysis revealed positive correlation among some epipelic algae (C. lacustris, C. affinis, N. romana and S. ulna) and DO, $\mathrm{Na}, \mathrm{N}: \mathrm{P}, \mathrm{NO}_{3}$, TSS, and Turbidity. While a negative correlation observed among these species and EC, BOD5, $\mathrm{PO}_{4}, \mathrm{NO}_{2}, \mathrm{Ca}, \mathrm{SO}_{4}$, TOC and $\mathrm{C}: \mathrm{SiO}_{3}$.

C. menenghiana, C. placentula var. euglypta, $N$. viridula, A. affinis, and A. veneta showed positive correlation with the following factors (EC, BOD5, TH, light pentertion (LP), CA, $\mathrm{SO}_{4}, \mathrm{CO}_{2}, \mathrm{PO}_{4}, \mathrm{NO}_{2}, \mathrm{TOC}$ and $\mathrm{C}: \mathrm{SiO}$ ). While negative correlation with other factors (DO, Na, N:P, $\mathrm{NO}_{3}$, TSS and Turbidity).

The studied physicochemical parameters confirmed that the dominant species of epipelic algae in this investigation can be used as bioindicator for water quality. These factors reflected the clean to moderate water quality of the study sites [44] [49] [50].

\section{Conclusion}

The diatom community in Al-Shamiyah River reflected the level of water quality in terms of dominant species. The studied physicochemical parameters in this investigation also confirmed the water quality status (clean to moderate) of the river.

\section{References}

[1] Khthim, N.F., Al-Amari, M.J.Y. and Hassan, F.M. (2013) The Spatial and Temporal Distribution of Epipelic Algae and Related Environmental Factors in Neel Stream, Babil Province, Iraq. IJAS, 4, 23-32.

[2] Salman, J.M., Kalifa, A.T. and Hassan, F.M. (2013) Qualitative and Quantitative Study of Epipelic Algae and Related Environmental Parameters in AL-HILLA RIVER, Iraq. IJCR, 5, 3318-3327.

[3] Hassan, F.M. and Al-Bdulameer, S.H. (2014) Qualitative and Quantitative Study of Epipelic Algae in Tigris River 
within Baghdad City, Iraq. Journal Baghdad for Science, 11, 1074-1082.

[4] Alkam, F.M. and Al-Nashi, N.H. (2013) Some Physico-Chemical Properties of EastEuphrates Drainage with Effected of EpipelicAlgae/AL-Dawaniya/Iraq. Journal of Alqadisiyah for Pure Science, 18, 1-18.

[5] AL-Saadi, H.A., Pankow, H. and Huq, M.F. (1979) Algological Investigation in the Polluted Ashar Canal and Shatt Al-Arab in Basrah, Iraq. Internationale Revue der gesamten Hydrobiologie, 64, 527-540.

[6] Rimet, F. (2009) Benthic Diatom Assemblages and Their Correspondence with Ecological Classification: Case Study of Rivers in North-Eastern France. Hydrobiologia, 636, 137-151. http://dx.doi.org/10.1007/s10750-009-9943-1

[7] Poulićkova, A., Haŝler, P., Lysá Kova, M. and Spears, B. (2008) The Ecology of Fresh Water Epipelic Algae: An Update. Phycologia, 47, 437-450. http://dx.doi.org/10.2216/07-59.1

[8] Sigee, D.C. (2005) Freshwater Microbiology: Biodiversity and Dynamic Interactions of Microorganisms in the Freshwater Environment. John Wiley \& Sons Ltd., Chichester, 573.

[9] Atıcı, T. and Çalışkan, H. (2007) Effect of Some Environmental Variables on Benthic Shore Algae (Excluding Bacillariophyta) of Asartepe Dam (Ankara). International Journal of Natural and Engineering Sciences, 1, 9-22.

[10] Stevenson, R J. (1996) The Stimulation and Drag of Current. In: Stevenson, R.J., Bothwell, M.L. and Lowe, R.L. Eds., Algal Ecology: Freshwater Benthic Ecosystems, Academic Press, San Diego, California, 321-340.

[11] Sahin, B., Akar, B. and Bahceci, I. (2010) Species Composition and Diversity of Epipelic Algae in Balik Lake (SavsatArtvin, Turkey). Turkish Journal of Botany, 34, 441-448.

[12] Moore, J.W. (1974) Benthic Algae of Southern Baffin Island: II. The Epipelic Communities in Temporary Ponds. Journal of Ecology, 62, 809-819. http://dx.doi.org/10.2307/2258956

[13] Round, F.E. (1984) The Ecology of Algae. Cambridge University Press, Cambridge.

[14] Mooser, K.A., Macdonald, G.M. and Smol, J.P. (1996) Applications of Freshwater Diatoms to Geographical Research. Progress in Physical Geography, 20, 21-52. http://dx.doi.org/10.1177/030913339602000102

[15] Al-Lami, A.A., Al-Saadi, H.A., Kassim, T.I. and Farhan, R.K. (1999) Seasonal Change Epipelic Algae Communities in North Part of Euphartes River, Iraq. Journal of College of Education for Women, 10, 236-247.

[16] Amal, M.E. (2012) The Use of Diatom Indices for the Assessment of Shatt AL-Arab River Water Quality. Journal of Basrah Researches, 38, 114-124.

[17] APHA (American Public Health Association) (2003) Standard Methods for Examination of Water and Wastwater. 2nd Edition, Washington DC.

[18] Parsons, T.R., Maita, Y. and Lalli, C.M. (1984) A Manual of Chemical and Biological Methods for Seawater Analysis. Pergamon Press, Oxford.

[19] Gaudette, H.E., Flight, W.R., Toner, L. and Folger, D.W. (1974) An Inexpensive Titration Method for the Determination of Organic Carbon in Recent Sediments. Journal of Sedimentary Research, 44, 249-253.

[20] Magurran, A.E. (1988) Ecological Diversity and Its Measurement. Princeton University Press, Princeton, 264.

[21] Hadi, R.A.M., Al-Sabonchi, A.A. and Haroon, A.K.Y. (1984) Diatoms of the Shatt Al-Arab River Iraq. Nova Hedwigia, 39, 513-557.

[22] Prescott, G.W. (1973) Algae of the Western Great Lake Area. William C. Brow Co. Publisher, Dubuque.

[23] Germain, H. (1981) Flora des diatoms. Diatomophyceae eau douces et saumatres du massif. Armoricion et des contrees voisines d' Europe occindental. Sciete Nouvelle des Editim Boubee, Paris.

[24] Al-Handal, A.Y. (1994) Contribution to the Knowledge of Diatoms of Sawa Lake, Iraq. Nova Hedwiia, 59, $225-254$.

[25] Hassan, F.M., Hadi, R.W., Kassim, T.I. and Al-Hassany, J.S. (2012) Systematic Study of Epiphytic Algal after Restoration of Al-Hawizah Marshes, Southern of Iraq. International Journal of Aquatic Science, 3, 37-57.

[26] Al-Hassany, J. and Hassan, F.M. (2014) Taxonomic Study of Some Epiphytic Diatoms on Aquatic Plants from Al-Hawizah Marshes, Southern of Iraq. Asian Journal of Natural \& Applied Sciences, 3, 1-11.

[27] Hassan, F.M. and Shaawiat, A.O. (2015) Qualitative and Quantitative Study of Phytoplankton (Diatoms) in a Lotic Ecosystem, Iraq. International Journal of Aquatic Science, 6, in press.

[28] Hassan, F.M., Taylor, W.D., Al-Taee, M.M.S. and Al-Fatlaw, H.J.J. (2010) Phytoplankton Composition of Euphrates River in Al-Hindiya Barrage and Kifil City Region of Iraq. Journal of Environmental Biology, 31, 343-350.

[29] Almamoori, A.J., Hassan, F.M. and Kassim, T.I. (2012) Impact of Industrial Waste Water on the Properties of One Major Drainage in the Region of the Middle Euphrates/Iraq. International Journal of Chemical Sciences, 10, 17851798.

[30] Hassan, F.M., Salman, J.M., Alkam, F.A. and Jawad, H.J. (2014) Ecological Observations on Epipelic Algae in Euphrates River at Hindiya and Manathira, Iraq. International Journal of Advanced Research, 2, 1183-1194. 
[31] Salman, J.M., Hassan, F.H., Hadi, S.J. and Motar, A.A. (2014) An Ecological Study of Epiphytic Algae on Two Aquatic Macrophytes in Lotic Ecosystem. Asian Journal of Natural \& Applied Sciences, 3, 37-52.

[32] Scott, D.A., Ed. (1995) A Directory of Wetlands in the Middle East. IUCN, Gland and IWRB, Slimbridge.

[33] Wetzel, R.G. (2001) Limnology: Lake \& River Ecosystems. 3rd Edition, Academic Press (An Elsevier Science Imprint), San Francisco, New York, London, 429 p.

[34] Kuiper, J., Janse, J.H., Teurlinex, S., Verhoeven, J.T.A. and Alkemade, R. (2014) The Impact of River Regulation on the Biodiversity Intactness of Floodplain Wetlands. Wetlands Ecology and Management, 22, 647-658. http://dx.doi.org/10.1007/s11273-014-9360-8

[35] Ismail, A.M. and Hassan, F.H. (2007) Seasonal Variations of the Phytoplankton in Alwind River-Iraq. Iraq Journal of Aquatic, 2, 89-99.

[36] SWRCB (2002) Electrical Conductivity/Salinity Fact Sheet. In: The Clean Water Team Guidance Compendium for Watershed Monitoring and Assessment State Water Resources Control Board. http://www.swrcb.ca.gov/water_issues/programs/swamp/docs/cwt/guidance/3130en.pdf

[37] Manivanan, R. (2008) Water Quality Modeling: Rivers, Streams and Estuaries. New India Publishing, New Delhi, 305.

[38] Hassan, F.M. (1997) A Limnological Study on Hilla River. Al-Mustansiriya Journal of Science, 8, 22-30.

[39] Alobaidy, A.H.M., Abid, H.S. and Maulood, B.K. (2010) Application of Water Quality Index for Assessment of Dokan Lake Ecosystem, Kurdistan Region, Iraq. Journal of Water Resource and Protection, 2, 792-798. http://dx.doi.org/10.4236/jwarp.2010.29093

[40] Adakole, J.A., Balogun, J.K. and Haroon, A.K. (1984) Water Quality Impacts Assessment Associated with an Urban Stream in Zaria, Nigeria. NSEB, 2, 195-203.

[41] Acs, E., Szabo, K., Toth, B. and Kiss, K.T. (2004) Investigation of Benthic Algal Communities Especially Diatoms of Some Hungarian Streams in Connection with Reference Conditions of the Water Framework Directives. Acta Botanica Hungarica, 46, 255-278. http://dx.doi.org/10.1556/ABot.46.2004.3-4.1

[42] Muylaert, K., Sanches-perez, M.J., Teissier, S.S., Dauta, A. and Rervier, P. (2009) Eutrophication and Effect on Dissolved Si Concentrations in the Garonne River (France). Journal of Limnology, 68, 368-374. http://dx.doi.org/10.4081/jlimnol.2009.368

[43] Moonsyn, P., Peerapornpisal, Y., Swasdipan, N. and Pimmongkol, A. (2009) Benthic Diatoms Diversity and Water Quality in the Mekong River in the Vicinity of Ubon Ratchathani Province. Journal of Microscopy Society of Thailand, 23, 47-51.

[44] Leelahakrie, K.P. and Peerapornpisal, Y. (2010) Diversity of Benthic Diatoms and Water Quality of the Ping River Northern Thailand. The International Journal Published by the Thai Society of High Education Institutes on Environment, EnvironmentAsia, 3, 82-94.

[45] Tomas, W.E. (2007) The Role of Wave Disturbance on Lentic, Benthic Algae Community Structure and Diversity. M.Sc. Thesis, Bowling Green State University, Bowling Green.

[46] Welch, E.B., Jacoby, J.M., Oener, R.R. and Seeley, M.R. (1988) Nuisance Biomass Levels of Periphytic Algae in Streams. Hydrobiologia, 157, 161-168. http://dx.doi.org/10.1007/BF00006968

[47] Dodds, W.K. (2006) Eutrophication and Trophic State in Rivers and Streams. Limnology and Oceanography, 51, 671680. http://dx.doi.org/10.4319/lo.2006.51.1 part 2.0671

[48] Guts, J.J.M., Sarneel, J.M., Willers, B.J.C., Roelofs, J.G.M., Verhoeven, J.A. and Lamers, L.P.M. (2009) Interacting Effects of Sulphate Pollution, Sulphide Toxicity and Eutrophication on Vegetation Development in Fens: A Mesocosm Experiment. Environmental Pollution, 157, 2072-2081. http://dx.doi.org/10.1016/j.envpol.2009.02.024

[49] Krammer, K. and Lange-Bertalot, H. (1986) Bacillariophyceae. Teil 1. Naviculaceae. Sußwassweflora von Mitteleuropa, Bd. 2, berg. Von A. Pascher. Gustav Fisher Verlag, Stuttgart.

[50] Duong, T., Mazel, A., Coste, M., Dang, D. and Boudou, A. (2007) Dynamics of Diatom Colonization Process in Some Rivers Influenced by Urban Pollution (Hanoi, Vietnam). Ecological Indicators, 7, 839-851. http://dx.doi.org/10.1016/j.ecolind.2006.10.003 
Scientific Research Publishing (SCIRP) is one of the largest Open Access journal publishers. It is currently publishing more than 200 open access, online, peer-reviewed journals covering a wide range of academic disciplines. SCIRP serves the worldwide academic communities and contributes to the progress and application of science with its publication.

Other selected journals from SCIRP are listed as below. Submit your manuscript to us via either submit@scirp.org or Online Submission Portal.
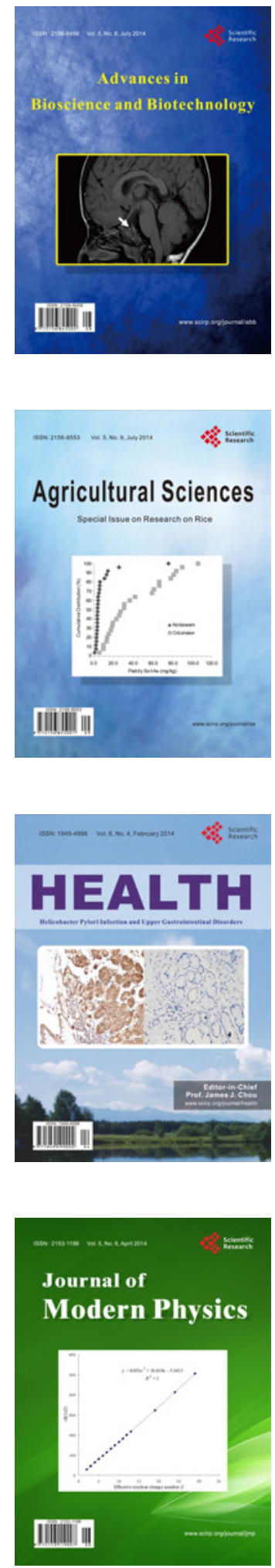
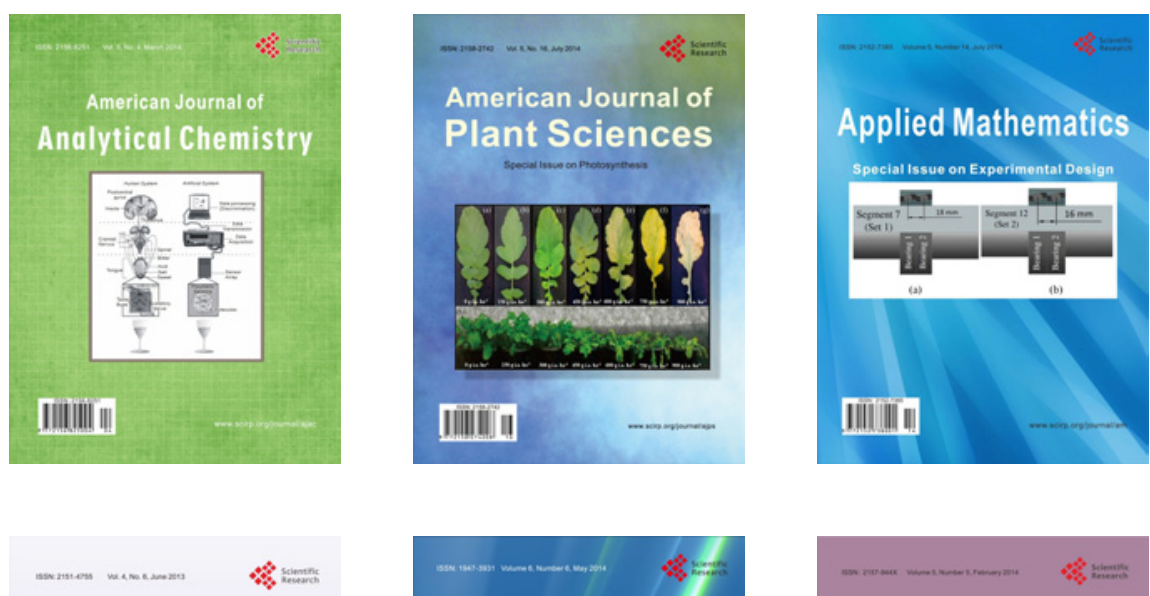

Creative Education
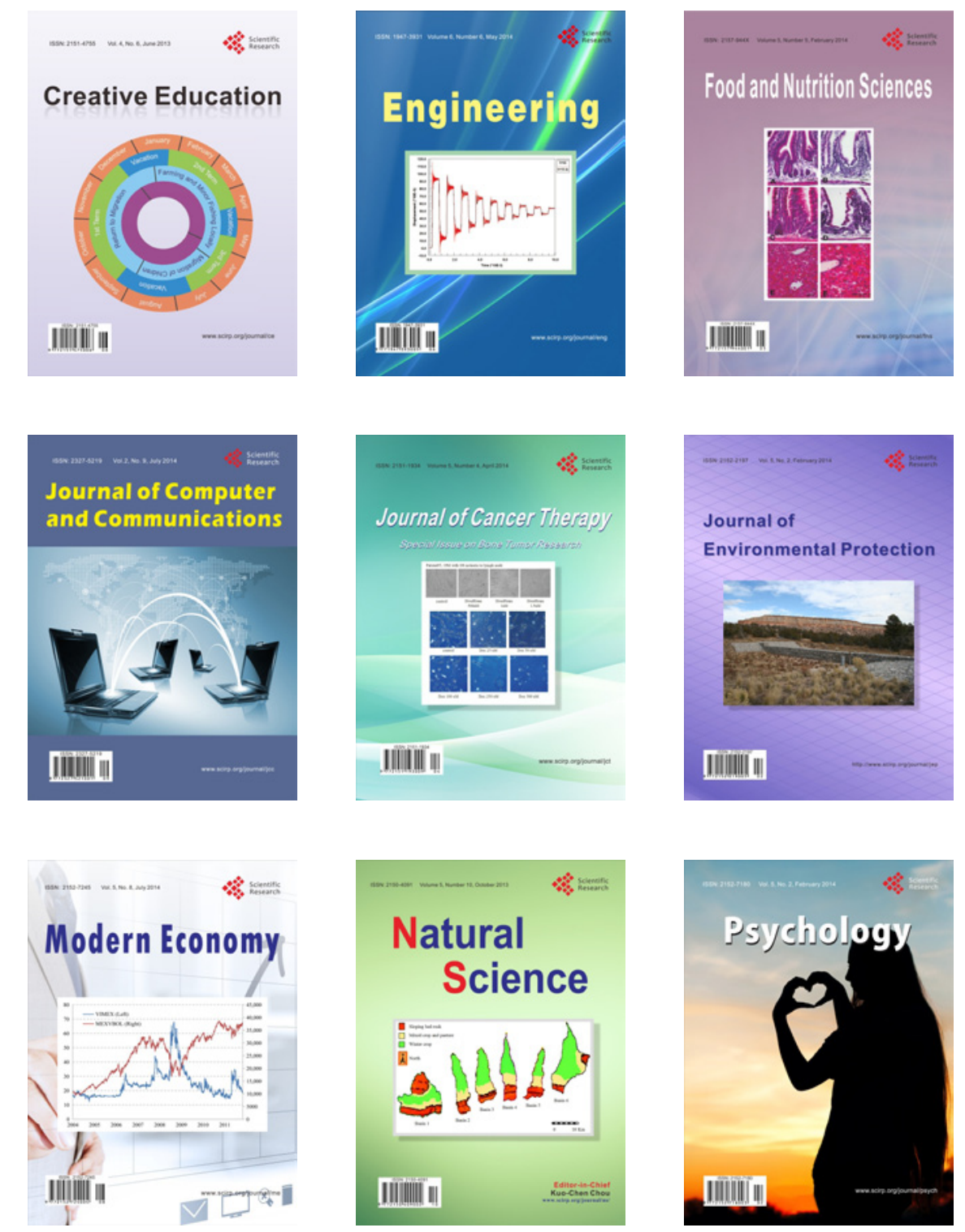